ISSN:2528-9527

E-ISSN:2528-9535

Yll Year:7

Cilt Volume:7

Sayı Issue: 13

\title{
Özel Yetenekli Öğrencilerin Liderlik Becerilerinin Bazı Değişkenler Açısından İncelenmesi ${ }^{1}$
}

DOI: $10.26466 /$ opus.361971

\author{
* \\ $\underline{\text { Eray Demirçelik }}^{*}$ - Ayşe Sena Karacabey ${ }^{* *}$ - Esra Dilara Cenan ${ }^{* * *}$ \\ ${ }^{*}$ Dr., Çetin Şen Bilim Sanat Merkezi, Kayseri/Türkiye \\ E-Posta: eraydemircelik@gmail.comＯRCID: 0000-0002-3165-7211 \\ **Çetin Şen Bilim Sanat Merkezi, Kayseri/Türkiye \\ E-Posta: aysesenakaracabey@gmail.com ORCID: 0000-0001-6556-6222 \\ ***Çetin Şen Bilim Sanat Merkezi, Kayseri/Türkiye \\ E-Posta: dilara05.02@gmail.com \\ ORCID: 0000-0003-0726-807X
}

\section{Öz}

Bu araştırmada, Bilim ve Sanat Merkezlerine devam eden özel yetenekli öğrencilerin liderlik becerilerinin ve liderliğe ilişkin algılarının bazı değişkenler açısından incelenmesi amaçlanmıştır. Araştırmada karma yöntem kullanılmıştır. Araştırmanın örneklemini, 2016-2017 eğitim öğretim döneminde Kayseri Çetin Şen Bilim ve Sanat Merkezine devam eden, 5.6 .7 ve 8. sinff seviyesinde toplam 135 öğrenci oluşturmaktadır. Araştırmada, Ogurlu (2012) tarafından geliştirilen Liderlik Becerileri Ölçeği, yarı yapılandırılmış form ve kişisel bilgi formu kullanılmıştır. Araştırma verileri SPSS istatistik paket program ve içerik analizi tekniğinden faydalanılarak analiz edilmiştir. Araştırmanın nicel boyutunda öğrencilerin liderlik becerisi düzeyleri cinsiyet, okul türü, sinıf, etkinliklere katılım durumu ve aile geliri değişkenleri açısından ele alınmıştır. Nitel boyutta ise, özel yetenekli öğrenciler tarafindan "liderlik" kavramı ile ilgili olarak toplam 68 adet geçerli metafor üretilmiş ve bu metaforlar üç kavramsal kategori altında toplanmıştır.

Anahtar Kelimeler: Özel yetenekli çocuklar, liderlik becerileri, liderlik algısı, liderlik metaforları

\footnotetext{
${ }^{1}$ Bu çalışma, aynı adla TÜBITAK 48. Lise Öğrencileri Araştırma Projeleri Yarışması Kayseri Bölge Finalinde sergilenen projeden üretilmiştir.
} 


\title{
Examination of Leadership Skills of Special Talen- ted Students in Terms of Some Variables
}

DOI: $10.26466 /$ opus.361971

\begin{abstract}
This study is aimed to examine the perceptions of leadership skills and leadership of special talented students attending to Science and Art Centers in terms of some variables. The Mixed method was used in the study. The sample consisted of 135 students from 5th.6th.7th and 8th grade, attending to Kayseri Çetin Şen Science and Art Center in 2016-2017 academic year. The Leadership Skills Scale by Ogurlu (2012) and a semi-structured form and personal information form were used. The data were analyzed using SPSS 22 software and content analysis technique. In the quantitative dimension of the study, the leadership skill levels of the students were examined in terms of gender, school type, class, participation in active participation and family income variables. In the qualitative dimension, a total of 68 valid metaphors were created by special talented students regarding the concept of "leadership" and these metaphors were grouped under three conceptual categories.
\end{abstract}

Key Words : Special talented students, leadership skills, perception of leadership, leadership metaphors 


\section{Giriş}

Özel yetenekli bireylere tüm toplumlarda rastlamak mümkündür. Özel yetenekli bireyler kimi zaman yetenekleri ile toplumun dikkatini çekmiş, kimi zaman ise keşfedilememiş kabiliyetler olarak hayatlarını sürdüregelmişlerdir. Günümüz rekabet dünyasında, devletler hayatta kalabilmek ve refah seviyelerini artırabilmek için bilim, sanat, spor gibi birçok alanda nitelikli ve yetişmiş insan gücüne ihtiyaç duymaktadırlar. Beyin gücü, bilgi çağı olarak adlandırılan bu çağda en önemli ekonomik girdiler arasında sayılmaktadır (Levent, 2012). Özellikle son yıllarda birçok ülkenin, özel yetenekli insanlarının bilgi ve kabiliyetlerinden yararlanma ve onları en iyi şekilde yetiştirmeye yönelik eğitici faaliyetlere hız verdiği görülmektedir (Baykoç Dönmez, 2005). Genel nüfusun \%2'si oranında özel yetenekli birey olduğu düşünülürse, bu bireylerin eğitimlerine erken yaşlarda başlanılması ve yeteneklerinin gelişimi büyük önem taşımaktadır (Davaslıgil, 2004).

Türk eğitim sisteminde yükseköğretimi bitiren bir birey için yaşamın ortalama 15 yılı, yaşamın ana hedefinin başarı olduğu okullarda geçmektedir (Toprak ve Selçuklu, 2012). Türk eğitim tarihinde Enderun gibi özel eğitim alanında çok özel bir kurum geçmişine sahip olunmasına rağmen, özel yeteneklilerin eğitimine yönelik çalışmaların ancak son yıllarda hız kazandığı görülmektedir. Türkiye'de özel yetenekli çocukların eğitimine yönelik en önemli uygulamalardan birisi, 80 ilde 106 merkezde hizmet veren ve yaklaşık 25 bin özel yetenekli öğrencinin eğitim aldığı Bilim ve Sanat Merkezlerinin (BİLSEM) kurulmasıdır (Milli Eğitim Bakanlığ1 [MEB], 2016). Milli Eğitim Bakanlığı Bilim ve Sanat Merkezleri Yönergesi'ne göre, özel yetenekli birey; yaşıtlarına göre daha hızlı öğrenen; yaratıcılık, sanat, liderliğe ilişkin kapasitede önde olan, özel akademik yeteneğe sahip, soyut fikirleri anlayabilen, ilgi alanlarında bağımsız hareket etmeyi seven ve yüksek düzeyde performans gösteren birey olarak tanımlanmaktadır (MEB, 2016a). Özel tanılama sınavlarıla BİLSEM'lere gelen öğrencilere, ilkokul ikinci sınıf seviyesinden başlayarak lise son sınıf seviyesine kadar ilgi, yetenek ve kabiliyetleri doğrultusunda farklı alanlarda eğitim alma ve kendini geliştirme imkânları verilmektedir. Liderlik eğitimleri de bu alanlardan birisidir. Özel yetenekli bireyler, gerek zekâları, gerek mizah anlayışları gerekse ileri 
görüşlü olmaları sayesinde, karşılaştıkları sorunlarla başa çıkabilme, empatik dinleme, aldıkları sorumlulukları yerine getirme, grup ruhu oluşturma, girişken olma ve karar alırken objektif olma gibi liderlik becerileri açısından gelişime açık bir grup olma özelliği gösterirler (Ersoy ve Avc1, 2004).

Liderlik alanında çalışma yapan birçok araştırmacı liderliğin sonradan geliştirilebilen bir özellik olduğunu ve liderlik becerilerinin öğretilebileceği ve standart okul müfredatında uygulanmasının mümkün olduğunu savunmaktadır (Bennis, 1999; Fertman ve Long, 1990; Goldsmith 2000'den akt. Ogurlu, 2012). Liderlik becerilerinin ölçülmesi son dönem araştırmacılarının üzerinde düşünmeye başladığı bir konudur (Can, 2007; Demirçelik ve Korkmaz, 2017; Korkmaz, 2006). Cubba (2004), liderliğin ölçülmesini; kendini değerlendirme, grup dinamikleri becerileri üyelerinin lideri değerlendirmesi, birlikte olduğu kişilerce yapılan değerlendirme ve bağımsız gözlemcilerin değerlendirmeleri olmak üzere dört şekilde ele almıştır (Akt. Emir ve Acar, 2007). Liderlik tanılama ve tarama ölçekleri üzerinde akademik çalışmalar devam etmektedir (Döş, 2016; Kılınç ve Özdemir, 2016; Ogurlu, 2012). Çocuk ve gençlerin liderlik özelliklerine yönelik alan araştırmalarının sayısının artırılması yönünde çalışmalar yapılmaktadır (Clark ve Clark, 1994'den akt. Ogurlu, 2012).

Yapılan literatür taramasında, üstün yetenekli çocukların öfkeyle başa çıkma ve karar verme becerileri (Ersoy ve Deniz, 2016), devam ettikleri okulları ile bilim ve sanat merkezine ilişkin metaforik algıları (Aslan ve Doğan, 2016), iletişim becerileriyle ilgili görüşleri (Koç, 2015), üstün yetenekli çocukların anne babalarının karşılaştıkları güçlükler (Çamdeviren, 2014), mesleki olgunluk düzeyleri ile algıladıkları sosyal destek düzeyleri arasındaki ilişki (Bozgeyikli, Doğan ve Işıklar, 2010), psikolojik ihtiyaçlarının bazı değişkenlere göre incelenmesi (Doğan, 2015) gibi farklı değişkenlere yönelik çalışmalar olmasına karşın özel yetenekli öğrencilerin liderlik becerileri üzerine (Emir ve Acar, 2007) alanda çok az çalı̧̧ma olduğu görülmüştür. BİLSEM'lerin sayısının gelecek yıllarda artacağ düşünüldüğünde, bu kurumların araştırmacılar tarafından her yönden incelenmesi, özel yetenekli öğrencilerin geliştirilmesine yönelik çalışmaların bilimsel bulgularla ortaya konulması, verilen eğitimin nitelik ve niceliği açısından önem taşımaktadır. Çünkü bilindiği üzere Türkiye'nin 
yaşam koşulları ve mevcut sınav sistemleri öğrencilerin kişilik özelliklerine göre tercih yapmalarını zorlaştırabilmektedir (Çetinkaya ve Toprak, 2016). Bu çalışmada Bilim ve Sanat Merkezlerinde öğrenim gören özel yetenekli çocukların liderlik becerilerinin geliştirilmesi ve liderliğin önemi vurgulanmaya çalışılmıştır. Bu çalışmanın özel yetenekliler alanındaki tüm paydaşlara, politika belirleyicilerine ve alan araştırmacılarına fayda sağlayacağı düşünülmektedir.

$\mathrm{Bu}$ çalışmanın amacı, özel yetenekli öğrencilerin liderlik beceri düzeylerini belirleyebilmek ve liderlik becerileri ile farklı değişkenler arasında anlamlı bir ilişkinin bulunup bulunmadığını ortaya çıkarabilmektir. Bu temel amaç doğrultusunda aşağıdaki alt sorulara cevap aranmıştır.

1. Özel yetenekli öğrencilerin liderlik becerileri düzeyleri nasıldır?

2. Özel yetenekli öğrencilerin liderlik becerileri cinsiyete göre farklılık göstermekte midir?

3. Özel yetenekli öğrencilerin liderlik becerileri okul türüne göre farklılık göstermekte midir?

4. Özel yetenekli öğrencilerin liderlik becerileri sınıf düzeyine göre farklılık göstermekte midir?

5. Özel yetenekli öğrencilerin liderlik becerileri etkinliklere katılma durumuna göre farklılık göstermekte midir?

6. Özel yetenekli öğrencilerin liderlik becerileri ailelerin gelir düzeyine göre farklılık göstermekte midir?

\section{Yöntem}

Araştırmada, nitel ve nicel boyutlu karma yöntem kullanılmıştır. Greene, Krayder ve Mayer (2005) sosyal bilimlerde, iki ya da daha fazla analiz veya veri toplama yolunun aynı araştırmada amaçlı olarak kullanılmasını karma yöntem olarak tanımlamışlardır (Akt. Beycioğlu ve Aslan, 2012). Araştırmanın nicel boyutunda, tarama modeli kullanılmıştır. Tarama modeli, geçmişte ya da hâlihazırda var olan durumu olduğu şekliyle betimlemeyi amaçlayan araştırma modelidir (Karasar, 2002). Araştırmanın nitel boyutunda, özel yetenekli öğrencilerin liderlik kavramına ilişkin sahip oldukları algılarını metaforlar yardımıyla belirleyebilmek için nitel 
araştırma desenlerinden olgubilim (phenomelogy) deseni kullanılmıştır. Metaforlar zengin bulgular elde etmek adına kullanılabilen nitel veri toplama araçlarıdır (Şimşek ve Yıldırım, 2011).

\section{Çalışma Grubu}

Araştırmanın çalışma grubunu, 2016-2017 eğitim öğretim döneminde Kayseri Çetin Şen Bilim ve Sanat Merkezine devam eden, 5.6.7 ve 8. sınıf seviyesinde toplam 135 özel yetenekli öğrenci oluşturmaktadır. Araştırmaya katılan öğrencilerin 58 (\%43,0)'i kız, 77 (\%57,0)'si erkektir.

\section{Verilerin Toplanması}

Araştırma verilerinin toplanmasında, öğrencilerin demografik bilgilerini elde etmek amacıyla kişisel bilgi formu, öğrencilerin liderlik kavramına ilişkin metaforlarını ortaya çıkarmak için "Liderlik denilince aklınıza gelen ilk ifadeyi, kelime/kelimeleri yazınız" sorusunun yer aldığı yarı yapılandırılmış form ve Liderlik Becerileri Ölçeğini (Ogurlu, 2012) içeren veri toplama seti kullanılmıştır. Araştırmacılar tarafından, 170 adet form dağıtılmış ve geri dönen 146 forma tek tek numara verilerek veri girişi yapılmıştır. Toplanan 11 form hata ve eksiklikler nedeniyle iptal edilmiştir. Hatasız ve eksiksiz doldurulan 135 adet formdan elde edilen bilgiler ile analizler yapılmıştır.

\section{Liderlik Becerileri Ölçeği (LİBÖ)}

Ogurlu (2012) tarafından geliştirilen Liderlik Becerileri Ölçeği (LïBÖ), $5,6,7$ ve 8. sınıf öğrencilerin liderlik becerilerini ölçmek amacıyla geliştirilmiş ve bu yaşlara uygulanabilecek, toplam 41 maddeden oluşmaktadır (Ek-1). Ölçekte 5’li Likert tipi dereceleme kullanılmıştır. Olumlu maddeler "Bana her zaman uygun =5", "Bana çoğunlukla uygun $=4$ ", "Bana bazen uygun = 3", "Bana çok az uygun =2" ve "Bana hiçbir zaman uygun değil =1" şeklinde 5' den 1'e doğru puanlanmış; olumsuz maddeler ise tersten hesaplanmıştır. Ölçeğin güvenirliliği .89 düzeyinde 
yüksek bir değer olarak bulunmuştur. Ölçeğin; 1,3,5,6,7,11,28,30. maddeleri sorun çözme; 20,21,23,24,25,40,41. maddeleri grup dinamikleri, 10,14,15,16,17,18. maddeleri hedef belirleme; 38,39,29. maddeleri azim; 37,35,26. maddeleri öfke kontrolü; 33,34,32,12. maddeleri çekingenlik; 2,22,19. maddeleri önderlik; 4,31. maddeleri yaratıcılık; 36,27,8. maddeleri empati, 9,13. maddeleri hitabet faktörleri için puanlanmaktadır. Ölçekten alınabilecek en düşük puan 41, en yüksek puan ise 205'dir. 10, 12, 15, 19, $26,29,32,33,34,35,37,38$, 39. maddeler ters madde olarak belirlenmiştir (Ogurlu, 2012).

\section{Verilerin Analizi}

$\mathrm{Bu}$ çalışmadaki istatistiksel analizler SPSS 22.0 paket programı kullanılarak yapılmıştır. Liderlik becerileri ölçeğinin tüm boyutlarından elde edilen puanların cinsiyet değişkenine göre farklılaşıp farklılaşmadığını incelemek için bağımsız grup T-testi, sınıf değişkenine göre farklılaşıp farklılaşmadığını incelemek için Kruskal Wallis-H testi, ilgili alt boyutlarda grupların puan ortalamaları arasındaki farkın kaynağını belirlemek amacıyla Mann Whitney U testi, ölçek puanlarının aile gelir durumuna göre anlamlı düzeyde farklılaşma durumunu ortaya koymak amacıyla tek yönlü varyans analizi (ANOVA) ve grupların puan ortalamaları arasındaki farkın kaynağını belirlemek amacıyla TUKEY testi kullanılmıştır. Araştırmanın nitel verilerinin analizinde ise içerik analiz yöntemi kullanılmıştır. İçerik analizinde, özel yetenekli öğrencilerin liderlik kavramına ilişkin geliştirdikleri metaforlar, word programı aracılığıly bilgisayara aktarılmış, adlandırma, eleme, gruplandırma ve geçerlik ve güvenirliğin sağlanması süreçlerinden oluşan beş aşamalı bir değerlendirme yapılmıştır (Saban, 2008). Nitel verilerin geçerlik ve güvenirliği sağlama aşamasında, üretilen metaforların kategorilerinin onaylanması amacıyla uzman görüşüne başvurulmuştur. Nitel çalışmalarda, uzman ve araştırmacı değerlendirmeleri arasındaki uyumun \%90 ve üzeri olduğu durumlarda geçerli bir güvenilirlik sağlanmış olmaktadır (Saban, 2008). Yaptığımız bu araştırmanın güvenirliği, Miles ve Huberman (1994)'nın formülü (Güvenirlik= Görüş birliği/Görüş birliği+Görüş ayrılığ1 x 100) ile hesaplanmıştır (Akt. Şenel ve Aslan, 2014). Katılımcıların verdiği cevaplar doğrultusunda "liderlik" kavramı ile ilgili olarak ortaya 
çıkan 68 metafordan üç tanesinde (lider, taht, bilmek) araştırmacılar ve uzman tarafından görüş ayrıllı̆ı olmuştur. Hesaplamalar sonucunda liderlik kavramına ait metafor sonuçlarının güvenirliği yaklaşık \% 95.7 olarak hesaplanmıştır. Frekansların hesaplanması ve verilerin yorumlanması aşamasında oluşturulan kategoriler tablolaştırılmış ve özel yetenekli öğrencilerin bu metaforları kullanma sıklıkları frekans ve yüzde olarak ifade edilmiştir. Elde edilen bulgulara göre veriler yorumlanmıştır.

\section{Bulgular}

Bu bölümde veri toplama araçları ile elde edilen verilerin ışığında ortaya çıkan bulgular sunulmuştur. Araştırma grubunu oluşturan öğrencilerin demografik bilgilerinin frekans ve yüzdelik dağılımlarına Tablo 1'de yer verilmiştir.

Tablo 1. Araştırma grubunu oluşturan öğrencilerin demografik özellikleri

\begin{tabular}{llcl}
\hline Değişken & Kategoriler & f & \% \\
\hline Cinsiyet & Kız & 58 & 43.0 \\
& Erkek & 77 & 57.0 \\
\hline \multirow{2}{*}{ Sınıf } & 5. sinıf & 29 & 21.5 \\
& 6.sinıf & 29 & 21.5 \\
& 7. sinıf & 59 & 43.7 \\
& 8.sinıf & 18 & 13.3 \\
\hline Okul Türü & Özel Okul & 64 & 47.4 \\
& Devlet Okulu & 71 & 52.6 \\
\hline Etkinlik & Katılmiyorum & 62 & 45.9 \\
& Düzenli sportif etkinliğe devam ediyorum & 55 & 40.7 \\
& Düzenli sanat etkinliğine devam ediyorum & 18 & 13.3 \\
\hline Gelir Düzeyi & Orta & 37 & 27.4 \\
& Orta üstü & 37 & 27.4 \\
& Yüksek & 31 & 23.0 \\
& Çok yüksek & 30 & 22.2 \\
\hline & Toplam & 135 & 100 \\
\hline
\end{tabular}

Tablo 1'de görüldüğü gibi araştırmaya katılan 135 özel yetenekli öğrencinin, 58'i (\%43.0) kız, 77'si (\%57.0) erkektir. Araştırmaya katılan öğrencilerin, $29^{\prime}$ u (\%21.5) 5. sinıfa, $29^{\prime}$ u (\%21.5) 6. sinıfa, 59'u (\%43.7) 7. sinıfa ve $17^{\prime}$ si (\%12.6) 8. sınıfa gitmektedir. Araştırma grubu öğrencilerinin, $64^{\prime} \ddot{u}$ (\%47.4) özel okulunda, 71'i (\%52.6) devlet okulunda eğitim görmektedir. 
Herhangi bir etkinlik yapıyor musunuz sorusuna öğrencilerin 62'si (\%45.9) hayır, 55'i (\%40.7) düzenli sportif etkinlik, 18'i (\%13.3) düzenli sanat etkinliklerine katıldığını belirtmiştir. Öğrencilerin 37'si (\%27.4) orta, 37 'si (\%27.4) orta üstü, 31'i (\%23) yüksek, 30'u (\%22.2) çok yüksek gelir grubunda olduğunu belirtmiştir.

Tablo 2'de özel yetenekli öğrencilerin LïBÖ’nün alt boyutlarına ilişkin ortalama ve standart sapma değerleri verilmiştir.

Tablo 2. LİB̈̈'nün alt boyutlarına ilişkin ortalama ve standart sapma değerleri

\begin{tabular}{llllll}
\hline Alt Boyutlar & N & En düşük & En yüksek & $\bar{x}$ & S \\
\hline Sorun çözme & 135 & 19.00 & 40.00 & 33.30 & 4.74 \\
Grup dinamikleri & 135 & 23.00 & 35.00 & 31.99 & 2.92 \\
Hedef belirleme & 135 & 12.00 & 30.00 & 24.62 & 3.76 \\
Azim & 135 & 3.00 & 15.00 & 12.13 & 2.72 \\
Öfke kontrolü & 135 & 3.00 & 15.00 & 8.83 & 3.42 \\
Çekingenlik & 135 & 4.00 & 20.00 & 13.95 & 3.90 \\
Önderlik & 135 & 3.00 & 15.00 & 11.15 & 2.86 \\
Yaratıcllk & 135 & 4.00 & 10.00 & 8.84 & 1.33 \\
Empati & 135 & 3.00 & 15.00 & 12.94 & 2.43 \\
Hitabet & 135 & 2.00 & 10.00 & 8.62 & 1.46 \\
\hline Toplam & 135 & 106.0 & 199.0 & 166.42 & 17.23 \\
\hline
\end{tabular}

Tablo 2'de görüldüğü gibi araştırmaya katılan 135 özel yetenekli öğrencinin, sorun çözme puanlarına ait aritmetik ortalama değeri $\left({ }^{\bar{x}}\right) 33.30$; standart sapma değeri (S) 4.74, grup dinamikleri puanlarına ait aritmetik ortalama değeri $\left({ }^{\bar{x}}\right) 31.99$; standart sapma değeri (S) 2,92' dır. Hedef belirleme puanlarına ait aritmetik ortalama değeri $\left({ }^{\bar{x}}\right)$ 24.62; standart sapma değeri (S) 3,76, azim puanlarına ait aritmetik ortalama değeri $\left({ }^{\bar{x}}\right)$ 12.13; standart sapma değeri (S) 2,72' dir. Öfke kontrolü puanlarına ait aritmetik ortalama değeri $\left({ }^{\bar{x}}\right)$ 8.83; standart sapma değeri (S) 3,42, çekingenlik puanlarına ait aritmetik ortalama değeri $\left({ }^{\bar{x}}\right) 13.95$; standart sapma değeri (S) 3,90'dir. Yaratıcılık puanlarına ait aritmetik ortalama değeri $\left({ }^{\bar{x}}\right) 8.84$; standart sapma değeri (S) 1,33, empati puanlarına ait aritmetik ortalama değeri $\left({ }^{\bar{x}}\right)$ 12.94; standart sapma değeri (S) 2,43'dir. Hitabet puanlarına ait aritmetik ortalama değeri $\left({ }^{\bar{x}}\right) 8.62$; standart sapma değeri (S) 1,46'dir. Elde edilen ortalama değerler gözönüne alındığında, ölçeğin öfke kontrolü alt 
boyutunda orta düzey, diğer tüm alt boyutlarda yüksek düzeyde olduğu görülmektedir.

Tablo 3'te özel yetenekli öğrencilerin LİBÖ puanlarının cinsiyet değişkenine göre bağımsız grup T- Testi sonuçları verilmiştir.

Tablo 3. LїB̈̈ puanlarının cinsiyet değişkenine göre bă̆ımsız grup t- testi sonuçları

\begin{tabular}{|c|c|c|c|c|c|c|}
\hline Boyutlar & Cinsiyet & $\mathbf{N}$ & $\bar{x}$ & Ss. & $\mathbf{t}$ & $\mathbf{p}$ \\
\hline \multirow{2}{*}{ Sorun çözme } & $\mathrm{K}_{12}$ & 58 & 34,08 & 4,60 & \multirow{2}{*}{1,675} & \multirow{2}{*}{,096 } \\
\hline & Erkek & 77 & 32,71 & 4,78 & & \\
\hline \multirow{2}{*}{ Grup dinamikleri } & $\overline{K_{1 Z}}$ & 58 & 32,68 & 2,53 & \multirow{2}{*}{$2,521^{*}$} & \multirow{2}{*}{,013 } \\
\hline & Erkek & 77 & 31,46 & 3,09 & & \\
\hline \multirow{2}{*}{ Hedef belirleme } & $\overline{K_{1 z}}$ & 58 & 25,25 & 3,89 & \multirow{2}{*}{1,698} & \multirow{2}{*}{,092 } \\
\hline & Erkek & 77 & 24,15 & 3,61 & & \\
\hline \multirow{2}{*}{ Azim } & $\overline{K_{1 z}}$ & 58 & 12,79 & 2,54 & \multirow{2}{*}{$2,485^{*}$} & \multirow{2}{*}{,014 } \\
\hline & Erkek & 77 & 11,63 & 2,77 & & \\
\hline \multirow{2}{*}{ Öfke kontrolü } & $\overline{K_{1 z}}$ & 58 & 8,84 & 3,52 & \multirow{2}{*}{,023 } & \multirow{2}{*}{,982 } \\
\hline & Erkek & 77 & 8,83 & 3,36 & & \\
\hline \multirow{2}{*}{ Çekingenlik } & $\overline{K_{1 Z}}$ & 58 & 14,55 & 3,38 & \multirow{2}{*}{1,549} & \multirow{2}{*}{ 124 } \\
\hline & Erkek & 77 & 13,50 & 4,21 & & \\
\hline \multirow{2}{*}{ Önderlik } & $\overline{\mathrm{K}} 1 \mathrm{z}$ & 58 & 11,79 & 2,93 & \multirow{2}{*}{$2,277^{*}$} & \multirow{2}{*}{,024 } \\
\hline & Erkek & 77 & 10,67 & 2,74 & & \\
\hline \multirow{2}{*}{ Yaratıcilık } & $\mathrm{K}_{1 \mathrm{z}}$ & 58 & 8,89 & 1,18 & \multirow{2}{*}{,393 } & \multirow{2}{*}{ 695 } \\
\hline & Erkek & 77 & 8,80 & 1,44 & & \\
\hline \multirow{2}{*}{ Empati } & $\overline{K_{1 z}}$ & 58 & 13,41 & 2,27 & \multirow{2}{*}{1,946} & \multirow{2}{*}{,054 } \\
\hline & Erkek & 77 & 12,59 & 2,50 & & \\
\hline \multirow{2}{*}{ Hitabet } & $\mathrm{K} 1 \mathrm{z}$ & 58 & 8,81 & 1,33 & \multirow{2}{*}{1,298} & \multirow{2}{*}{ 197 } \\
\hline & Erkek & 77 & 8,48 & 1,55 & & \\
\hline \multirow{2}{*}{ Toplam } & $\mathrm{K}_{1 \mathrm{z}}$ & 58 & 171,13 & 17,11 & \multirow{2}{*}{$2,830 *$} & \multirow{2}{*}{,005 } \\
\hline & Erkek & 77 & 162,87 & 16,56 & & \\
\hline
\end{tabular}

Tablo 3 incelendiğinde öğrencilerin cinsiyetlerine göre liderlik becerilerinin sorun çözme, hedef belirleme, öfke kontrolü, çekingenlik, yaratıc1lık, empati ve hitabet alt boyutlarında gruplar arasında anlamlı bir farklılik yoktur.

Bununla birlikte ölçeğin grup dinamikleri alt boyutunda kız öğrencilerin ortalamasının 32,68 erkek öğrencilerin ortalamasının ise 31,46 olduğu görülmektedir. Grupların puan ortalamaları arasındaki farkın anlamlıl1ğını test etmek amaciyla hesaplanan $t$ değeri $(t=2,521, p<, 05)$ grupların puan ortalamaları arasındaki farkın ,05 düzeyinde anlamlı olduğunu ifade etmektedir. Bu bulguya göre kız öğrencilerin grup dinamikleri, erkek öğrencilerin grup dinamiklerinden anlamlı düzeyde yüksektir. 
Ölçeğin azim alt boyutunda kız öğrencilerin ortalamasının 12,79, erkek öğrencilerin ortalamasının ise 11,63 olduğu görülmektedir. Grupların puan ortalamaları arasındaki farkın anlamlılığını test etmek amacıyla hesaplanan $t$ değeri $(t=2,485, p<, 05)$ grupların puan ortalamaları arasındaki farkın ,05 düzeyinde anlamlı olduğunu ifade etmektedir. Bu bulguya göre kız öğrencilerin azim alt boyutu puanları, erkek öğrencilerin azim alt boyutu puanlarından anlamlı düzeyde yüksektir.

Ölçeğin önderlik alt boyutunda kız öğrencilerin ortalamasının 11,79 erkek öğrencilerin ortalamasının ise 10,67 olduğu görülmektedir. Grupların puan ortalamaları arasındaki farkın anlamlılığını test etmek amacıyla hesaplanan $t$ değeri $(t=2,277, p<, 05)$ grupların puan ortalamaları arasındaki farkın ,05 düzeyinde anlamlı olduğunu ifade etmektedir. Bu bulguya göre kız öğrencilerin önderlik becerileri, erkek öğrencilerin önderlik becerilerinden anlamlı düzeyde yüksektir.

Ölçeğin tüm alt boyutlarının genel ortalamasında, kız öğrencilerin ortalamasının 171,13, erkek öğrencilerin ortalamasının ise 162,87 olduğu görülmektedir. Grupların puan ortalamaları arasındaki farkın anlamlılığını test etmek amaciyla hesaplanan $t$ değeri $(t=2,830, p<, 05)$ grupların puan ortalamaları arasındaki farkın, 05 düzeyinde anlamlı olduğunu ifade etmektedir. Bu bulguya göre kız öğrencilerin liderlik becerileri, erkek öğrencilerin liderlik becerilerinden anlamlı düzeyde yüksektir.

Tablo 4'te özel yetenekli öğrencilerin LïB̈̈ puanlarının okul türü değişkenine göre bağımsız grup T- Testi sonuçları verilmiştir.

Tablo 4 incelendiğinde öğrencilerin okul türlerine göre liderlik becerilerinin sorun çözme, hedef belirleme, azim, öfke kontrolü, önderlik, yaratıcılık, empati, hitabet alt boyutlarında ve genel puanda gruplar arasında anlamlı bir farklılık yoktur.

Ölçeğin grup dinamikleri alt boyutunda özel okula giden öğrencilerin ortalamasının 31,12 devlet okuluna giden öğrencilerin ortalamasının ise 32,77 olduğu görülmektedir. Grupların puan ortalamaları arasındaki far$k ı n$ anlamlılığın test etmek amaciyla hesaplanan $t$ değeri $(t=-3,404, p<, 05)$ grupların puan ortalamaları arasındaki farkın ,05 düzeyinde anlamlı olduğunu ifade etmektedir. 


\begin{tabular}{|c|c|c|c|c|c|c|}
\hline \multicolumn{7}{|c|}{ Tablo 4. LїВÖ puanlarının okul değişkenine göre bağımsız grup t- testi sonuçları } \\
\hline Boyutlar & Okul türü & $\mathbf{N}$ & $\bar{x}$ & Ss. & $\mathbf{t}$ & $\mathrm{p}$ \\
\hline \multirow{2}{*}{ Sorun çözme } & Özel okul & 64 & 33,07 & 5,158 & \multirow{2}{*}{,- 523} & \multirow{2}{*}{602} \\
\hline & Devlet okulu & 71 & 33,50 & 4,358 & & \\
\hline \multirow{2}{*}{ Grup dinamikleri } & Özel okul & 64 & 31,12 & 3,359 & \multirow{2}{*}{$-3,404^{*}$} & \multirow{2}{*}{,001 } \\
\hline & Devlet okulu & 71 & 32,77 & 2,205 & & \\
\hline \multirow{2}{*}{ Hedef belirleme } & Özel okul & 64 & 24,29 & 3,684 & \multirow{2}{*}{,- 976} & \multirow{2}{*}{,331 } \\
\hline & Devlet okulu & 71 & 24,92 & 3,829 & & \\
\hline \multirow{2}{*}{ Azim } & Özel okul & 64 & 12,00 & 2,719 & \multirow{2}{*}{,- 538} & \multirow{2}{*}{,592 } \\
\hline & Devlet okulu & 71 & 12,25 & 2,750 & & \\
\hline \multirow{2}{*}{ Öfke kontrolü } & Özel okul & 64 & 8,89 & 3,357 & \multirow{2}{*}{ 172 } & \multirow{2}{*}{864} \\
\hline & Devlet okulu & 71 & 8,78 & 3,500 & & \\
\hline \multirow{2}{*}{ Çekingenlik } & Özel okul & 64 & 14,73 & 3,497 & \multirow{2}{*}{$2,235^{*}$} & \multirow{2}{*}{,027 } \\
\hline & Devlet okulu & 71 & 13,25 & 4,132 & & \\
\hline \multirow{2}{*}{ Önderlik } & Özel okul & 64 & 11,06 & 3,049 & \multirow{2}{*}{,- 357} & \multirow{2}{*}{,722 } \\
\hline & Devlet okulu & 71 & 11,23 & 2,712 & & \\
\hline \multirow{2}{*}{ Yaratıcılik } & Özel okul & 64 & 8,82 & 1,375 & \multirow{2}{*}{,- 135} & \multirow{2}{*}{,893 } \\
\hline & Devlet okulu & 71 & 8,85 & 1,301 & & \\
\hline \multirow{2}{*}{ Empati } & Özel okul & 64 & 12,53 & 2,672 & \multirow{2}{*}{$-1,905$} & \multirow{2}{*}{,059 } \\
\hline & Devlet okulu & 71 & 13,32 & 2,156 & & \\
\hline \multirow{2}{*}{ Hitabet } & Özel okul & 64 & 8,56 & 1,510 & \multirow{2}{*}{-,448 } & \multirow{2}{*}{655} \\
\hline & Devlet okulu & 71 & 8,67 & 1,432 & & \\
\hline \multirow{2}{*}{ Toplam } & Özel okul & 64 & 165,10 & 19,284 & \multirow{2}{*}{,- 839} & \multirow{2}{*}{,403 } \\
\hline & Devlet okulu & 71 & 167,60 & 15,198 & & \\
\hline
\end{tabular}

Bulgulara göre devlet okuluna giden öğrencilerin grup dinamikleri, özel okula giden öğrencilerin grup dinamiklerinden anlamlı düzeyde yüksektir.

Ölçeğin çekingenlik alt boyutunda, özel okula giden öğrencilerin ortalamasının 14,73 devlet okuluna giden öğrencilerin ortalamasının ise 13,25 olduğu görülmektedir. Grupların puan ortalamaları arasındaki farkın anlamlılığını test etmek amaciyla hesaplanan $t$ değeri $(t=2,235, p<, 05)$ grupların puan ortalamaları arasındaki farkın, 05 düzeyinde anlamlı olduğunu ifade etmektedir. Bu bulguya göre özel okula giden öğrencilerin çekingenlik alt boyutu puanları, devlet okuluna giden öğrencilerin çekingenlik alt boyutu puanlarından anlamlı düzeyde yüksektir.

Tablo 5'de özel yetenekli öğrencilerin LİBÖ Puanlarının sınıf değişkenine göre Kruskal Wallis-H Testi sonuçları verilmiştir. 
Tablo 5. LİÖ puanlarının sınıf değişkenine göre Kruskal Wallis-H testi sonuçlarn

\begin{tabular}{|c|c|c|c|c|c|c|}
\hline Boyutlar & Siniflar & $\mathbf{N}$ & Sira Ort. & $x^{2}$ & $\mathrm{p}$ & FARK \\
\hline \multirow{4}{*}{ Sorun çözme } & 5. sinif & 29 & 72,53 & \multirow{4}{*}{8,23} & \multirow{4}{*}{,041 } & \multirow{4}{*}{$\begin{array}{l}\text { 6. Sinıf }>7 \text {. Sinif } \\
\text { 7. Sinıf }<8 \text {. Sinıf }\end{array}$} \\
\hline & 6. sinif & 29 & 77,69 & & & \\
\hline & 7. sinif & 59 & 57,40 & & & \\
\hline & 8. sinif & 17 & 80,26 & & & \\
\hline \multirow{5}{*}{ Grup dinamikleri } & 5. sinif & 29 & 72,08 & \multirow{4}{*}{6,02} & \multirow{4}{*}{ 111 } & \\
\hline & 6. sinif & 29 & 78,74 & & & \\
\hline & 7. sinif & 59 & 59,12 & & & \\
\hline & 8. sinif & 17 & 73,29 & & & \\
\hline & $\overline{5 . \operatorname{sinif}}$ & 29 & 63,70 & \multirow{4}{*}{4,15} & \multirow{4}{*}{,245 } & \\
\hline \multirow{3}{*}{ Hedef belirleme } & 6. sinif & 29 & 73,40 & & & \\
\hline & 7. sinif & 59 & 63,33 & & & \\
\hline & 8. sinif & 17 & 82,59 & & & \\
\hline \multirow{4}{*}{ Azim } & 5. sinif & 29 & 78,18 & \multirow{4}{*}{6,07} & \multirow{4}{*}{ 108 } & \\
\hline & 6. sinif & 29 & 76,26 & & & \\
\hline & 7. sinif & 59 & 60,29 & & & \\
\hline & 8. sinif & 17 & 62,71 & & & \\
\hline \multirow{4}{*}{ Öfke kontrolü } & 5. sinif & 29 & 78,45 & \multirow{4}{*}{9,18} & \multirow{4}{*}{,027 } & \\
\hline & 6. sinif & 29 & 68,79 & & & $\begin{array}{l}\text { 5. Sinif }>8 . \text { Sinif } \\
6 . \text { Sinif }>8 \text { Sinif }\end{array}$ \\
\hline & 7. sinif & 59 & 69,47 & & & $\begin{array}{l}\text { 6. Sinif }>8 \text {. Sinit } \\
7 \text { Sinif }>8 \text { Sinif }\end{array}$ \\
\hline & 8. sinif & 17 & 43,12 & & & \\
\hline \multirow{4}{*}{ Çekingenlik } & $5 . \operatorname{sinif}$ & 29 & 67,23 & \multirow{4}{*}{, 52} & \multirow{4}{*}{,913 } & \\
\hline & 6. sinif & 29 & 64,43 & & & \\
\hline & 7. sinif & 59 & 70,54 & & & \\
\hline & 8. sinif & 17 & 66,62 & & & \\
\hline \multirow{4}{*}{ Önderlik } & $\overline{5 . \operatorname{sinif}}$ & 29 & 74,80 & \multirow{4}{*}{4,84} & \multirow{4}{*}{ 183 } & \\
\hline & 6. sinif & 29 & 72,16 & & & \\
\hline & 7. sinif & 59 & 59,81 & & & \\
\hline & $\underline{\text { 8. sinif }}$ & 17 & 77,32 & & & \\
\hline \multirow{4}{*}{ Yaratıcilık } & $\overline{5 . \operatorname{sinif}}$ & 29 & 78,27 & \multirow{4}{*}{8,30} & \multirow{4}{*}{,040 } & \\
\hline & 6. sinif & 29 & 77,29 & & & 5. Sinıf $>7$. Sinıf \\
\hline & 7. sinif & 59 & 58,19 & & & 6. Sinıf $>7$. Sinıf \\
\hline & 8. sinif & 17 & 68,06 & & & \\
\hline & 5. sinif & 29 & 78,82 & & & \\
\hline Fmpati & 6. sinif & 29 & 75,09 & & & \\
\hline Empat1 & 7. sinif & 59 & 58,77 & 6,94 & , & \\
\hline & $\underline{\text { 8. sinif }}$ & 17 & 68,85 & & & \\
\hline & 5. sinif & 29 & 77,75 & & & \\
\hline Hitahet & 6. sinif & 29 & 71,74 & & & \\
\hline Hitabet & 7. sinif & 59 & 63,23 & 3,82 & 281 & \\
\hline & 8. sinif & 17 & 60,97 & & & \\
\hline
\end{tabular}

Tablo 5 incelendiğinde LïBÖ puanlarının sınıf değişkenine göre, grup dinamikleri, hedef belirleme, azim, çekingenlik, önderlik, empati, hitabet 
alt boyutlarında anlamlı düzeyde bir farklılaşmanın olmadığı görülmektedir.

Bununla birlikte sorun çözme, öfke kontrolü, yaratıcılık alt boyutlarında, sınıf değişkenine göre gruplar arasında anlamlı bir farklılaşmanın olduğu belirlenmiştir. İlgili alt boyutlardaki grupların puan ortalamaları arasındaki farkın kaynağını belirlemek amacıyla gruplar arasında ikili karşılaştırmalar yapılmıştır.

Buna göre LỉBÖ ölçeğinin sorun çözme alt boyutunda; 6 . ve 7. sınıflar ile 7. ve 8. sinıflar, öfke kontrolü boyutunda; 5 . ve 8 . sinıflar, 6 . ve 8 . sinıflar ile 7. ve 8. siniflar, yaratıcilık boyutunda; 5 . ve 7. siniflar ile 6. ve 7. siniflar arasında anlamlı bir farklılık olduğu görülmektedir. Bu bulgudan hareketle sıra ortalamaları dikkate alındığında, 6. sınıf öğrencilerinin 7. sınıf öğrencilerinden ve 8 . sınıf öğrencilerinin 7.sınıf öğrencilerinden daha iyi sorun çözme becerisine sahip olduğu söylenilebilir. Öfke kontrolü sıra ortalamaları dikkate alındığında, 5., 6. ve 7. sınıf öğrencilerinin 8. sınıfa giden öğrencilere göre daha iyi durumda oldukları söylenilebilir. Yaratıcılık boyutu sıra ortalamaları dikkate alındığında, 5. ve 6. sınıfların 7. sınıflara göre üstün bir durumda olduğu söylenilebilir.

Tablo 6'da özel yetenekli öğrencilerin LİBÖ puanlarının etkinlik değişkenine göre Kruskal Wallis-H Testi değerleri verilmiştir.

Tablo 6 incelendiğinde LїÖ puanlarının etkinlik değişkenine göre, grup dinamikleri, hedef belirleme, azim, öfke kontrolü, önderlik, yaratıc1lık ve empati alt boyutlarında anlamlı düzeyde bir farklılaşmanın olmadığı görülmektedir

Bununla birlikte sorun çözme, çekingenlik ve hitabet alt boyutlarında, etkinlik değişkenine göre gruplar arasında anlamlı bir farklılaşmanın olduğu belirlenmiştir. İlgili alt boyutlardaki grupların puan ortalamaları arasındaki farkın kaynağını belirlemek amacıyla gruplar arasında ikili karşılaştırmalar yapılmıştır. Buna göre sorun çözme, çekingenlik ve hitabet alt boyutlarında; herhangi bir etkinliğe düzenli katılmayanlar ile düzenli spor etkinliklerine devam edenler, hitabet alt boyutunda ise düzenli spor etkinliklerine devam edenler ile düzenli sanat etkinliklerine devam edenler arasında anlamlı bir farklılık olduğu görülmektedir. Bu bulgulardan hareketle sıra ortalamaları dikkate alındığında, düzenli spor etkinliklerine devam edenlerin düzenli olarak herhangi bir etkinliğe devam etmeyenlere göre daha iyi sorun çözme becerisine sahip olduğu söylenilebilir. 
Tablo 6. LİB̈̈ puanlarının etkinlik değişkenine göre Kruskal Wallis-H testi sonuçları

\begin{tabular}{|c|c|c|c|c|c|c|}
\hline Boyutlar & Etkinlik & $\mathbf{N}$ & Sira Ort. & $x^{2}$ & $\mathbf{p}$ & FARK \\
\hline \multirow{3}{*}{ Sorun çözme } & Katılmiyorum & 62 & 57,40 & \multirow{3}{*}{8,74} & \multirow{3}{*}{,013 } & Katılmiyorum > \\
\hline & Düzenli spor etkin devam ed. & 55 & 78,38 & & & Düzenli spor et. \\
\hline & Düzenli sanat etkin devam ed. & 18 & 72,78 & & & Devam ed. \\
\hline \multirow{3}{*}{ Grup dinamikleri } & Katılmiyorum & 62 & 66,12 & \multirow{3}{*}{,293 } & \multirow{3}{*}{, 864} & \\
\hline & Düzenli spor etkin devam ed. & 55 & 69,97 & & & \\
\hline & Düzenli sanat etkin devam ed. & 18 & 68,44 & & & \\
\hline \multirow{3}{*}{ Hedef belirleme } & Katılmiyorum & 62 & 63,35 & \multirow{3}{*}{1,63} & \multirow{3}{*}{, 441} & \\
\hline & Düzenli spor etkin devam ed. & 55 & 71,95 & & & \\
\hline & Düzenli sanat etkin devam ed. & 18 & 71,94 & & & \\
\hline \multirow{3}{*}{ Azim } & Katılmıyorum & 62 & 60,27 & \multirow{3}{*}{4,58} & \multirow{3}{*}{ 101 } & \\
\hline & Düzenli spor etkin devam ed. & 55 & 74,59 & & & \\
\hline & Düzenli sanat etkin devam ed. & 18 & 74,47 & & & \\
\hline \multirow{3}{*}{ Öfke kontrolü } & Katılmiyorum & 62 & 60,44 & \multirow{3}{*}{4,53} & \multirow{3}{*}{ 103 } & \\
\hline & Düzenli spor etkin devam ed. & 55 & 73,21 & & & \\
\hline & Düzenli sanat etkin devam ed. & 18 & 78,14 & & & \\
\hline \multirow{3}{*}{ Çekingenlik } & Katılmiyorum & 62 & 56,17 & \multirow{3}{*}{11,29} & \multirow{3}{*}{,004 } & Katılmiyorum < \\
\hline & Düzenli spor etkin devam ed. & 55 & 80,26 & & & Düzenli spor et. \\
\hline & Düzenli sanat etkin devam ed. & 18 & 71,28 & & & Devam ed. \\
\hline \multirow{3}{*}{ Önderlik } & Katılmiyorum & 62 & 59,43 & \multirow{3}{*}{5,92} & \multirow{3}{*}{, 052} & \\
\hline & Düzenli spor etkin devam ed. & 55 & 73,75 & & & \\
\hline & Düzenli sanat etkin devam ed. & 18 & 79,97 & & & \\
\hline \multirow{3}{*}{ Yaratıcılık } & Katılmiyorum & 62 & 61,99 & \multirow{3}{*}{4,04} & \multirow{3}{*}{ 133 } & \\
\hline & Düzenli spor etkin devam ed. & 55 & 75,59 & & & \\
\hline & Düzenli sanat etkin devam ed. & 18 & 65,50 & & & \\
\hline \multirow{3}{*}{ Empati } & Katılmiyorum & 62 & 64,62 & \multirow{3}{*}{3,51} & \multirow{3}{*}{,173 } & \\
\hline & Düzenli spor etkin devam ed. & 55 & 66,77 & & & \\
\hline & Düzenli sanat etkin devam ed. & 18 & 83,39 & & & \\
\hline \multirow{3}{*}{ Hitabet } & Katılmiyorum & 62 & 61,82 & \multirow{3}{*}{7,03} & \multirow{3}{*}{,030 } & Katılmiyorum < \\
\hline & Düzenli spor etkin devam ed. & 55 & 78,27 & & & Düzenli spor et. \\
\hline & Düzenli sanat etkin devam ed. & 18 & 57,89 & & & Devam ed. \\
\hline
\end{tabular}

Düzenli olarak herhangi bir etkinliğe katılmayanların çekingenlik alt boyutunda düzenli spor etkinliklerine devam edenlere oranla daha iyi ortalamaya sahip olduğu söylenilebilir. Hitabet alt boyutunda düzenli spor etkinliklerine devam edenlerin, düzenli sanat etkinliklerine devam edenlerden daha iyi bir ortalamaya sahip olduğu dolayısıyla hitabet becerilerinin yüksek olduğu düşünülebilir.

Öğrencilerin, LİBÖ puanlarının aile gelir durumuna göre anlamlı düzeyde farklılaşma durumunu ortaya koymak amaciyla tek yönlü varyans 
analizi (ANOVA) yapılmıştır. Yapılan analize ilişkin bulgular Tablo 7'de verilmiştir.

Tablo 7 incelendiğinde sorun çözme alt boyutunda en yüksek puan ortalamasının 35,7333 ile aile gelir durumu çok yüksek olan öğrencilere ait olduğu, bunu sırasıyla 33,3784 ile orta, 32,4516 ile yüksek ve 31,9730 ile orta üstü gelir seviyelerinin izlediği görülmektedir.

Grup dinamikleri alt boyutunda en yüksek puan ortalamasının 32,4667 ile aile gelir durumu çok yüksek olan öğrencilere ait olduğu, bunu sırasıyla 32,4595 ile orta, 31,9459 ile orta üstü ve 31,0323 ile yüksek gelir seviyelerinin izlediği görülmektedir.

Hedef belirleme alt boyutunda en yüksek puan ortalamasının 26,3000 ile aile gelir durumu çok yüksek olan öğrencilere ait olduğu, bunu sırasıyla 24,3784 ile orta üstü, 24,2581 ile yüksek ve 23,8378 ile orta gelir seviyelerinin izlediği görülmektedir.

Azim alt boyutunda en yüksek puan ortalamasının 12,2903 ile aile gelir durumu yüksek olan öğrencilere ait olduğu, bunu sırasıyla 12,2162 ile orta, 12,0811 ile orta üstü ve 11,9333 ile çok yüksek gelir seviyelerinin izlediği görülmektedir.

Öfke kontrolü alt boyutunda en yüksek puan ortalamasının 9,2162 ile aile gelir durumu orta üstü olan öğrencilere ait olduğu, bunu sırasıyla 9,1290 ile yüksek, 8,9459 ile orta ve 7,9333 ile çok yüksek gelir seviyelerinin izlediği görülmektedir.

Çekingenlik alt boyutunda en yüksek puan ortalamasının 15,5333 ile aile gelir durumu çok yüksek olan öğrencilere ait olduğu, bunu sırasıyla 14,2581 ile yüksek, 13,6486 ile orta üstü ve 12,7297 ile orta gelir seviyelerinin izlediği görülmektedir.

Önderlik alt boyutunda en yüksek puan ortalamasının 12,0000 ile aile gelir durumu çok yüksek olan öğrencilere ait olduğu, bunu sırasıyla 11,2258 ile yüksek, 10,8919 ile orta üstü ve 10,6757 ile orta gelir seviyelerinin izlediği görülmektedir.

Yaratıcılık alt boyutunda en yüksek puan ortalamasının 9,2000 ile aile gelir durumu çok yüksek olan öğrencilere ait olduğu, bunu sırasiyla 9,1935 ile yüksek, 8,9459 ile orta ve 8,1622 ile orta üstü gelir seviyelerinin izlediği görülmektedir. 


\begin{tabular}{|c|c|c|c|c|}
\hline Boyutlar & Gelir & $\mathbf{N}$ & $\bar{x}$ & S. \\
\hline \multirow{4}{*}{ Sorun çözme } & Orta & 37 & 33,3784 & 4,75132 \\
\hline & Orta üstü & 37 & 31,9730 & 5,09077 \\
\hline & Yüksek & 31 & 32,4516 & 4,33466 \\
\hline & Çok yüksek & 30 & 35,7333 & 3,88572 \\
\hline \multirow{4}{*}{ Grup dinamikleri } & Orta & 37 & 32,4595 & 2,83426 \\
\hline & Orta üstü & 37 & 31,9459 & 2,48267 \\
\hline & Yüksek & 31 & 31,0323 & 3,28110 \\
\hline & Çok yüksek & 30 & 32,4667 & 3,02556 \\
\hline \multirow{4}{*}{ Hedef belirleme } & Orta & 37 & 23,8378 & 4,64587 \\
\hline & Orta üstü & 37 & 24,3784 & 3,06731 \\
\hline & Yüksek & 31 & 24,2581 & 3,52106 \\
\hline & Çok yüksek & 30 & 26,3000 & 3,18564 \\
\hline \multirow{4}{*}{ Azim } & Orta & 37 & 12,2162 & 2,87842 \\
\hline & Orta üstü & 37 & 12,0811 & 2,61808 \\
\hline & Yüksek & 31 & 12,2903 & 2,67324 \\
\hline & Çok yüksek & 30 & 11,9333 & 2,85190 \\
\hline \multirow{4}{*}{ Öfke kontrolü } & Orta & 37 & 8,9459 & 3,31617 \\
\hline & Orta üstü & 37 & 9,2162 & 3,66769 \\
\hline & Yüksek & 31 & 9,1290 & 3,10636 \\
\hline & Çok yüksek & 30 & 7,9333 & 3,55191 \\
\hline \multirow{4}{*}{ Çekingenlik } & Orta & 37 & 12,7297 & 3,98364 \\
\hline & Orta üstü & 37 & 13,6486 & 3,45781 \\
\hline & Yüksek & 31 & 14,2581 & 4,19498 \\
\hline & Çok yüksek & 30 & 15,5333 & 3,58862 \\
\hline \multirow{4}{*}{ Önderlik } & Orta & 37 & 10,6757 & 3,09169 \\
\hline & Orta üstü & 37 & 10,8919 & 2,42423 \\
\hline & Yüksek & 31 & 11,2258 & 2,83678 \\
\hline & Çok yüksek & 30 & 12,0000 & 3,06257 \\
\hline \multirow{4}{*}{ Yaratıcilık } & Orta & 37 & 8,9459 & 1,22352 \\
\hline & Orta üstü & 37 & 8,1622 & 1,59013 \\
\hline & Yüksek & 31 & 9,1935 & 1,07763 \\
\hline & Çok yüksek & 30 & 9,2000 & 1,06350 \\
\hline \multirow{4}{*}{ Empati } & Orta & 37 & 13,2162 & 2,05663 \\
\hline & Orta üstü & 37 & 13,4595 & 1,65990 \\
\hline & Yüksek & 31 & 12,4516 & 2,83829 \\
\hline & Çok yüksek & 30 & 12,5000 & 3,09337 \\
\hline \multirow{4}{*}{ Hitabet } & Orta & 37 & 8,4054 & 1,58919 \\
\hline & Orta üstü & 37 & 8,5946 & 1,30084 \\
\hline & Yüksek & 31 & 8,4194 & 1,82161 \\
\hline & Çok yüksek & 30 & 9,1333 & ,93710 \\
\hline
\end{tabular}

Empati alt boyutunda en yüksek puan ortalamasının 13,4595 ile aile gelir durumu orta üstü olan öğrencilere ait olduğu, bunu sırasıyla 13,2162 
ile orta, 12,5000 ile çok yüksek ve 8,4194 ile yüksek gelir seviyelerinin izlediği görülmektedir.

Hitabet alt boyutunda en yüksek puan ortalamasının 9,1333 ile aile gelir durumu çok yüksek olan öğrencilere ait olduğu, bunu sırasiyla 8,5946 ile orta üstü, 8,4194 ile yüksek ve 8,4054 ile orta gelir seviyelerinin izlediği görülmektedir.

Aile gelir durumuna göre, özel yetenekli öğrencilerin liderlik becerileri farklılaşmasına ilişkin varyans analizi sonuçları Tablo $8^{\prime}$ de verilmiştir.

Tablo 8 incelendiğinde LİBÖ’nün grup dinamikleri, azim, öfke kontrolü, önderlik, empati, hitabet alt boyutlarında aile gelir düzeyleri açısından anlamlı bir farkın olmadığı görülmektedir.

Bununla birlikte sorun çözme alt boyutunda hesaplanan $F$ değeri $(\mathrm{F}=4,217 ; \mathrm{p}<, 05)$, hedef belirleme alt boyutunda hesaplanan $\mathrm{F}$ değeri $(F=2,782 ; \mathrm{p}<, 05)$, çekingenlik alt boyutunda hesaplanan $F$ değeri $(F=3,134$; $\mathrm{p}<, 05)$ ve yaratıcılık alt boyutunda hesaplanan $F$ değeri $(F=5,172 ; p<, 05)$ ilgili boyutlarda gruplar arasında ,05 düzeyinde anlamlı bir farkın oldugunu ifade etmektedir. Bu alt boyutlarda grupların puan ortalamaları arasındaki farkın kaynağını belirlemek amacıyla TUKEY testi yapılmıştır.

Aile gelir durumu açısından, sorun çözme alt boyutundaki puan ortalamaları arasındaki fark incelendiğinde çok yüksek gelir durumu ile orta üstü gelir ve yüksek gelir durumları arasında ,05 düzeyinde anlamlı bir farklılaşmanın olduğu Tablo 8' de görülmektedir. Bu bulguya göre aile gelir durumu çok yüksek olan öğrencilerin, sorun çözme düzeylerinin aile gelir durumu orta üst ve yüksek gelir grubunda bulunan öğrencilere göre daha yüksek olduğu söylenebilir.

Aile gelir durumu açısından, hedef belirleme alt boyutundaki puan ortalamaları arasındaki fark incelendiğinde çok yüksek gelir durumu ile orta gelir durumları arasında ,05 düzeyinde anlamlı bir farklılaşmanın olduğu Tablo 8'de görülmektedir. Bu bulguya göre aile gelir durumu çok yüksek olan öğrencilerin, hedef belirleme düzeylerinin aile gelir durumu orta gelir grubunda bulunan öğrencilere göre daha yüksek olduğu söylenebilir. 
Tablo 8. Aile gelir durumuna göre liderlik beceri düzeylerine ilişkin varyans analizi sonuçları

\begin{tabular}{|c|c|c|c|c|c|c|c|}
\hline Boyutlar & Gelir & KT & sd & KO & $\mathbf{F}$ & $\mathbf{p}$ & TUKEY \\
\hline \multirow{3}{*}{ Sorun çözme } & Gruplar Arası & 265,328 & 3 & 88,443 & $4,217^{*}$ & ,007 & \multirow{3}{*}{$\begin{array}{l}\text { Çok yüksek > Orta } \\
\text { Çok yüksek > Yüksek }\end{array}$} \\
\hline & Grup İçi & 2747,220 & 131 & 20,971 & & & \\
\hline & Toplam & 3012,548 & 134 & & & & \\
\hline \multirow{3}{*}{ Grup dinamikler } & Gruplar Arası & 43,477 & 3 & 14,492 & 1,727 & 165 & \\
\hline & i Grup İçi & 1099,515 & 131 & 8,393 & & & \\
\hline & Toplam & 1142,993 & 134 & & & & \\
\hline \multirow{3}{*}{ Hedef belirleme } & Gruplar Arası & 113,516 & 3 & 37,839 & $2,782^{*}$ & 044 & Çok yüksek > Orta \\
\hline & Grup İçi & 1781,965 & 131 & 13,603 & & & \\
\hline & Toplam & 1895,481 & 134 & & & & \\
\hline \multirow{3}{*}{ Azim } & Gruplar Arası & 2,319 & 3 & 773 & 102 & ,959 & \\
\hline & Grup İçi & 995,281 & 131 & 7,598 & & & \\
\hline & Toplam & 997,600 & 134 & & & & \\
\hline \multirow{3}{*}{ Öfke kontrolü } & Gruplar Arası & 32,902 & 3 & 10,967 & ,936 & 425 & \\
\hline & Grup İçi & 1535,513 & 131 & 11,721 & & & \\
\hline & Toplam & 1568,415 & 134 & & & & \\
\hline \multirow{3}{*}{ Çekingenlik } & Gruplar Arası & 136,601 & 3 & 45,534 & $3,134^{*}$ & ,028 & Çok yüksek > Orta \\
\hline & Grup İçi & 1903,132 & 131 & 14,528 & & & \\
\hline & Toplam & 2039,733 & 134 & & & & \\
\hline \multirow{3}{*}{ Önderlik } & Gruplar Arası & 32,638 & 3 & 10,879 & 1,333 & 266 & \\
\hline & Grup İçi & 1069,095 & 131 & 8,161 & & & \\
\hline & Toplam & 1101,733 & 134 & & & & \\
\hline \multirow{3}{*}{ Yaratıcılık } & Gruplar Arası & 25,176 & 3 & 8,392 & $5,172^{*}$ & ,002 & Orta $>$ Orta üstü \\
\hline & Grup İçi & 212,558 & 131 & 1,623 & & & Yüksek > Orta üstü \\
\hline & Toplam & 237,733 & 134 & & & & Çok yüksek > Orta üstü \\
\hline \multirow{3}{*}{ Empati } & Gruplar Arası & 26,000 & 3 & 8,667 & 1,473 & 225 & \\
\hline & Grup İçi & 770,637 & 131 & 5,883 & & & \\
\hline & Toplam & 796,637 & 134 & & & & \\
\hline \multirow{3}{*}{ Hitabet } & Gruplar Arası & 10,880 & 3 & 3,627 & 1,716 & 167 & \\
\hline & Grup İçi & 276,853 & 131 & 2,113 & & & \\
\hline & Toplam & 287,733 & 134 & & & & \\
\hline
\end{tabular}

Aile gelir durumu açısından, çekingenlik alt boyutundaki puan ortalamaları arasındaki fark incelendiğinde çok yüksek gelir durumu ile orta gelir durumları arasında ,05 düzeyinde anlamlı bir farklılaşmanın olduğu görülmektedir. Bu bulguya göre aile gelir durumu çok yüksek olan öğrencilerin çekingen olma düzeylerinin aile gelir durumu orta gelir grubunda bulunan öğrencilere göre daha yüksek olduğu söylenebilir.

Aile gelir durumu açısından, yaratıcılık alt boyutundaki puan ortalamaları arasındaki fark incelendiğinde orta, yüksek ve çok yüksek gelir du- 
rumları ile orta üstü gelir durumu arasında ,05 düzeyinde anlamlı bir farklılaşmanın olduğu görülmektedir. Bu bulguya göre aile gelir durumu orta, yüksek ve çok yüksek olan öğrencilerin, yaratıcılık düzeylerinin aile gelir durumu orta üstü gelir grubunda bulunan öğrencilere göre daha yüksek olduğu söylenebilir.

Araştırmada elde edilen nitel bulgulara göre, özel yetenekli öğrenciler tarafından "liderlik" kavramı ile ilgili olarak toplam 68 adet geçerli metafor üretilmiş ve bu metaforlar üç kavramsal kategori altında toplanmıştır. Tablo 9'da araştırmaya katılan öğrencilerin, "liderlik" kavramına ilişkin ürettikleri metaforların kategorilere göre dağılımı verilmiştir.

Tablo 9. Liderlik kavramına ilişkin metaforlarn kategorilere göre dağılımı

\begin{tabular}{|c|c|c|c|}
\hline $\begin{array}{l}\text { Liderlik Metafor } \\
\text { Kategorileri }\end{array}$ & $\begin{array}{c}f \\
(\%)\end{array}$ & Liderlik Metaforları & $\begin{array}{c}f \\
(\%)\end{array}$ \\
\hline Kişi ve Meslek & $\begin{array}{l}162 \\
(53,28)\end{array}$ & $\begin{array}{l}\text { Önder (40), Yönetici (34), Atatürk (26), Başkan (17), } \\
\text { Rehber (8), Kendim (7), Kaptan (7), Öğretmen (6), } \\
\text { Komutan (3), Lider (2), Padişah (2), İzci (2), Hitler } \\
\text { (1), Rütbe (1),Taht (1), Görev (1), Kurtarıcı (1), Va- } \\
\text { zife (1), Babam (1), Emir (1) }\end{array}$ & $\begin{array}{l}20 \\
(29,42)\end{array}$ \\
\hline $\begin{array}{l}\text { Davranışsal } \\
\text { Özellikler }\end{array}$ & $\begin{array}{l}115 \\
(37,83)\end{array}$ & $\begin{array}{l}\text { İleri görüşlülük (15), Adil (11), Sorumluluk (7), Ce- } \\
\text { saret (7), Güç (6), Kararlı (6), Dürüstlük (6), Güven } \\
\text { (5), Beyin gücü (4), Saygı (4), Hoşgörü (4), Hizlı çö- } \\
\text { züm bulabilme (3), Özgüven (3), Fedakârlık (3), Ba- } \\
\text { şarı (3), Çalışkan (3), Beceri (2), Azimli (2), Sözün } \\
\text { geçmesi (2), Yaratıı (2), Planlı (2), İrade (2), Sada- } \\
\text { kat (2), Soğukkanlılık (1), Koruyucu (1), Harika (1), } \\
\text { Kusursuz (1), İkna yeteneği (1), Mutlu (1), Geleceği } \\
\text { gören (1), Bilmek (1), Şahsiyet (1), Güzel davranış } \\
\text { (1), Disiplin (1), }\end{array}$ & $\begin{array}{l}34 \\
(50,00)\end{array}$ \\
\hline Sosyal Özellikler & $\begin{array}{l}27 \\
(8,89)\end{array}$ & $\begin{array}{l}\text { Düzen (7), Eşitlik (3), Kontrol (3), Toplum (2), Se- } \\
\text { çim (2), Üstünlük (2), Millet sevgisi (1), Oy (1), De- } \\
\text { mokrasi (1), Dayanışma (1), Farklılık (1), Terbiye } \\
\text { (1), Grup (1), Yardımlaşma (1) }\end{array}$ & $\begin{array}{l}14 \\
(20,58)\end{array}$ \\
\hline
\end{tabular}

Tablo 9'da görüldüğü gibi katılımcılar tarafından en çok tercih edilen "kişi ve meslek" olarak liderlik (\%53.28) kategorisidir. Katılımcılar tarafından kullanılan metaforlarla ikinci sırada "davranışsal özelliklere" göre liderlik (\%37.83), üçüncü sırada "sosyal özelliklere" göre liderlik (\%8.89) kategorisi gelmektedir. Öğrencilerin "liderlik" kavramını en fazla, önder 
(40), yönetici (34), Atatürk (26), başkan (17) ve ileri görüşlülük (15) metaforlarıyla anlattıkları görülmektedir.

\section{Tartışma ve Sonuç}

Bu çalışmanın amacı, özel yetenekli öğrencilerin liderlik beceri düzeylerini belirleyebilmek ve liderlik becerileri ile bazı değişkenler arasında anlamlı bir ilişkinin bulunup bulunmadığını belirlemek amacıyla yapılmıştır. Özel yetenekli çocukların liderlik becerileri ölçeği puan ortalamaları değerlendirildiğinde, ölçeğin tüm alt boyutlarında yüksek değerler aldıkları görülmektedir. Yapılan alan araştırmalarında, ortalama üstü zekânın liderliğin ön şartı olduğu, liderlerin yönettikleri gruptan daha fazla zekâya sahip olmalarının gerekliliğinin (Edmunds ve Yewchuk, 1996; Stogdill, 1981; Tannenbaum, 1983'den akt. Ogurlu, 2012) önemi vurgulanmıştır. 2013-2017 yıllarını kapsayan Üstün Yetenekli Öğrenciler için Meclis Araştırma Komisyonu Stratejik Eylem Raporunda da, özel yetenekli öğrencilerin yaşıtlarına göre daha üst liderlik becerilerine sahip olduğunu belirtilmektedir (Türkiye Büyük Millet Meclisi [TBMM], 2012). İnsanın doğuştan getirdiği yetenekleri, potansiyeli, gizilgüçleri vardır (Bozgeyikli, Derin ve Toprak, 2016). "Altının kıymetini sarraf bilir" atasözü gereği, özel yetenekli öğrencilerde var olan liderlik yetisini geliştirecek eğitim programlarının ve eğiticilerin geliştirilmesi, ülke genelinde ortak uygulanması geleceğimiz açısından önemlidir. Liderlik geliştirmenin önemi günümüzde daha belirginleşmekte ve liderlik geliştirme stratejik bir gereklilik halini almaktadır.

Özel yetenekli çocukların cinsiyetleri açısından LïBÖ puanları değerlendirildiğinde, kız öğrenciler lehine anlamlı bir fark bulunduğu görülmektedir. Özellikle grup dinamikleri, azim ve önderlik alt boyutlarında kız öğrenci becerilerinin erkeklere oranla daha yüksek olduğu tespit edilmiştir. Acar (2007) tarafından 11 yaş grubu öğrencileriyle yapılan çalışmada Roets Liderlik Değerlendirme Ölçeği'ne göre kız öğrencilerin liderlik beceri puanları erkek öğrencilerden yüksek çıkmıştır. Karnes ve D'Ilio (1989) ve Winter v.d. (2001)'lerinin yaptıkları araştırmalarda liderlik becerileri açısından kızlar lehine anlamlı farklılıklar bulunmuştur (Akt. Ogurlu, 2012). İlköğretim düzeyindeki öğrencilerin liderlik davranışlarına göre cinsiyet açısından bir farkının olmadığını savunan çalışmalar da 
mevcuttur (Kouzes ve Posner, 1997; McGhee, 2000; Posner ve Brodsky, 1994'den akt. Tüysüz, 2007).

Özel yetenekli çocukların gittikleri okul türü açısından LİBÖ puanları değerlendirildiğinde, grup dinamikleri ve çekingenlik alt boyutlarında devlet okuluna giden öğrenciler lehine anlamlı bir fark çıkmıştır. Ogurlu (2012)'nun yapmış olduğu araştırmada liderlik becerisi ile okul türleri arasında anlamlı bir fark oluşmamıştır. Özel yetenekli çocukların soyut ve rraksak düşünce yetenekleri erken yaşlardan itibaren geliştiği için zaman zaman grup içi iletişim ve farklı düşünce sorunları yaşayabilirler. Bu durumdaki çocuklar düşüncelerini kendilerine saklama yolunu tercih edebilirler (Oğurlu ve Yaman, 2010). Bu duruma göre, özel okula giden özel yetenekli öğrencilerin duygu ve düşüncelerini başkalarıyla paylaşmada güçlük yaşadıkları düşünülebilir.

Özel yetenekli çocukların sınıf değişkeni açısından LİBÖ puanları değerlendirildiğinde, sorun çözme alt botunda 6. ve 8 . sinıf öğrencileri ile 7 . sınıfa giden öğrenciler arasında anlamlı bir fark çıkmıştır. Öfke kontrolü alt boyutunda ise 5,6. ve 7. sınıfa giden öğrenciler ile 8 . sınıfa giden öğrenciler arasında anlamlı bir fark bulunmuştur. Yaratıcılık alt boyutunda 5 ve 6. sınıfa giden öğrenciler ile 7.sınıfa giden öğrenciler arasında anlamlı bir fark çıkmıştır. Bütün toplumlarda ergenlik dönemi problemlerin yoğunlaştığı bir dönem olarak gösterilmektedir (Kulaksızoğlu, 1990). Ergenlik döneminde yaşanan fiziksel, duygusal ve sosyal değişimler ergenlerin stresli olmalarına neden olmaktadır. Bu duruma bir de TEOG sınav stresi ve özel yetenekli çocuklardan beklentinin yüksek olması durumları eklenince üst sınıfların alt sınıflara göre öfke kontrolü sorunu yaşadığı ortaya çıkmıştır (Ersoy ve Deniz, 2016). Yaşanan dönemsel sıkıntıların yaratıcılık ve diğer boyutlara olan etkisi düşünüldüğünde, ergenlerin bu dönemi sorunsuz olarak atlatabilmesinin yollarının araştırılması gerekmektedir (Toprak ve Bozgeyikli, 2011).

Özel yetenekli çocukların kardeş sayısı ve kaçıncı çocuk değişkenleri ile liderlik becerileri arasında anlamlı bir ilişki bulunamamıştır. Day (1980) tarafından yapılan bir çalışmada, ilk doğan ya da son doğanın, arada doğanlara göre liderlik açısından daha avantajlı olduğu görülmüştür (Akt. Ogurlu, 2012). Ders dışı etkinliklere katılan öğrencilerin liderlik becerisi katılmayan öğrencilerle karşılaştırıldığında katılanlar lehine anlamlı fark bulunmuştur. Okul meclisi, kulüp çalışmaları, spor etkinlikleri 
gibi imkânlar öğrencilerin liderlik becerilerini geliştirebileceği imkanlar olarak görülmektedir (Smith, Smith, ve Barnette, 1991'den akt. Ogurlu, 2012). Çalışmamızda düzenli sportif etkinliklere katılanların katılmayan öğrencilere göre liderlik becerileri puan ortalamalarının yüksek çıması, okullarda ders dışı etkinliklerin önemini göstermektedir. Özel yetenekli çocukların aile gelir durumu açısından incelediğimizde, sorun çözme, hedef belirleme, çekingenlik ve yaratıcılık alt boyutlarında gelir durumu çok yüksek olan öğrenciler lehine anlamlı bir fark çıkmıştır. Eskicumalı ve Eroğlu (2001) araştırmalarında, ailenin gelirinin çocuklarının problem çözme yeteneklerinin gelişimine olumlu etkisi olduğunu yüksek gelire sahip aileler lehine anlamlı bir fark bulunduğunu belirtmişlerdir. Yaptığ1mı araştırmada özel yetenekli çocukların anne-baba eğitim durumu değişkenleri ile liderlik becerileri arasında anlamlı bir ilişki bulunamamıştır. Çamdeviren (2014) yapmış olduğu araştırmada özel yetenekli çocukların ailelerinin, çocuklarının özel yeteneklerini fark etme, sorularını cevaplandırabilme, zihinsel, sosyal, duyuşsal ve kişilik özelliklerinin farkında olabilme, iletişim becerileri ve sorunlarını çözebilme gibi konularda güçlükler yaşadıklarını saptamıştır.

Özel yetenekli öğrenciler "liderlik" kavramına yönelik toplam 68 adet geçerli metafor üretmiştir. Öğrenciler ürettikleri metaforlarda oldukça etkili ifadeler kullanmışlardır. Bu durum liderlik ile ilgili metafor üretebilen öğrencilerin liderliğin anlamını derinlemesine düşünebildiklerini göstermektedir. Araştırma katılımcılarının 5,6,7 ve 8. sınıf öğrencileri olduğu dikkate alınırsa bu çocukların Piaget'nin gelişim kuramına göre soyut işlemler dönemine denk gelmektedir. Bu dönemin özelliği olarak, analiz etme, karşılaştırma, soyut ilişkileri bulma, özgün bir şey üretme, eleştiriyel düşünme gibi özelliklerinin geliştirilmesine yönelik çalışmalar yapılmalıdır (Senemoğlu, 2007). Öğrenciler en fazla önder (40), yönetici (34), Atatürk (26), başkan (17), ileri görüşlülük (15) metaforlarını üretmişlerdir.

Her bilimsel araştırmanın konusu ve kapsamı açısından bazı sınırlılıkları bulunur (Bozgeyikli, Toprak ve Derin, 2016). Bu araştırma da Kayseri ilinden yalnızca 135 kişilik bir örneklem ile sınırlıdır. Bunun yanında liderlik eğitimi ile ilgili ülkemizde yeterince çalışma yapılmadığı görülmektedir. Özellikle ilköğretim düzeyinde daha fazla ve geniş ölçekli çalışmalar yapmak alan ve ülkemiz açısından çok faydalı olacaktır. Liderlik bece- 
rileri yüksek ve kabiliyetli kişilerin gelecekte önemli görevlere gelmesi geleceğimiz için büyük önem taşımaktadır. Özel yetenekli nesillerinin kabiliyetlerinden en üst düzeyde faydalanılabilmesi için okullarda ve BİLSEM'lerde uzman kişiler tarafından özel yetenekli öğrencilere liderlik ile ilgili grup etkinlikleri ve seminer çalışmaları yapılabilir. BİLSEM'lerin hem nitelik hem de niceliksel açıdan gelişmesi desteklenmelidir. Belediyeler ve sivil toplum kuruluşları da özel yetenekli çocuklara ve velilerine liderlik becerileri konusunda alan uzmanı kişiler tarafından seminerler vermesi sağlanabilir. Araştırma BİLSEM'e devam eden ortaokul öğrencileriyle gerçekleştirilmiştir. BİLSEM'lere devam edemeyen nice gizli kalmış özel kabiliyetlere sahip bireylerinde keşfedilmesi gerekmektedir. Bu bireylere ulaşmaya ve sahip oldukları kabiliyetlerinin geliştirilmesine yönelik çalışmalar yapılabilir. Liderlik becerilerinin geliştirilmesine yönelik çalışmaların erken yaşlardan itibaren başlatılması sağlanılabilir.

\section{KAYNAKÇA}

Acar, S. (2007). Raven SPM Plus Testi ve Roets liderlik değerlendirme ölçeğinin 10-11 yaş geçerlik, güvenirlik, on-norm çalışmalarına göre üstün zekâlı olan ve olmayan öğrencilerin liderlik özelliklerinin karşılaştırılması (Yayınlanmamış Yüksek Lisans Tezi). İstanbul Üniversitesi, Sosyal Bilimler Enstitüsü, İstanbul.

Aslan, H. ve Doğan, Ü. (2016). Üstün yetenekli öğrencilerin devam ettikleri okulları ile bilim ve sanat merkezine ilişkin metaforik algıları: karşılaştırmalı durum çalışması. Abant İzzet Baysal Üniversitesi Ĕ̆gitim Fakültesi Dergisi, 16(2), 335-350.

Baykoç Dönmez, N. (2005). Üstün yeteneklilerin eğitimleri ve bilim sanat merkezleri. Çocuk Gelişimi ve Ĕ̆itimi Dergisi, 1(2), 84-89.

Beycioğlu, K. ve Aslan, B. (2012). Öğretmen ve yöneticilerin öğretmen liderliğine ilişkin görüşleri: bir karma yöntem çalışması. Kuram ve Uygulamada Eğitim Yönetimi, 18(2), 191-223.

Bozgeyikli, H., Doğan, H. ve Işıklar, A. (2010). Üstün yetenekli öğrencilerin mesleki olgunluk düzeyleri ile algıladıkları sosyal destek düzeyleri arasındaki ilişkinin incelenmesi. Erciyes Üniversitesi Sosyal Bilimler Enstitüsü Dergisi, 28(1), 133-149. 
Bozgeyikli, H., Derin, S. ve Toprak, E. (2016). Üniversite öğrencilerinin mesleki değer algiları. International Journal of Contemporary Educational Studies, 2(1), 139-156.

Bozgeyikli, H., Toprak, E. ve Derin, S. (2016). Öğretmen adaylarının mesleki değer algılarının sıralama yargılarıyla ölçeklenmesi. Hak-İ̧̧ Uluslararası Emek ve Toplum Dergisi, 5(11), 204-225.

Can, N. (2007). Öğretmen liderliği becerileri ve bu becerilerin gerçekleştirilme düzeyi. Erciyes Üniversitesi Sosyal Bilimler Enstitüsü Dergisi, 22(1), 263-288.

Çetinkaya, Yıldız, E. ve Toprak, E. (2007). Psikolojik danışman adaylarının empatik eğilim, utangaçlık, olumsuz değerlendirilme korkusu ve sosyal beceri düzeylerinin farklı değişkenler açısından incelenmesi. Mediterranean Journal of Humanities, VI(2), 513-530.

Çamdeviren, Ş. (2014). Bilim ve Sanat Merkezine (Bilsem) devam eden üstün yetenekli çocukların anne babalarının karşılaştıkları güçlükler: Sakarya ili örneği (Yayımlanmamış Yüksek Lisans Tezi). Sakarya Üniversitesi Eğitim Bilimleri Enstitüsü, Sakarya.

Davaslıgil, Ü. (2004). Üstün çocuklar, ı. Türkiye üstün yetenekli çocuklar kongresi seçilmiş makaleler kitabı. Çocuk Vakfı Yayınları, İstanbul, 211218.

Demirçelik, E. ve Korkmaz, M. (2017). The relationship between the leadership styles of school managers and organizational cynicism according to the perceptions of secondary school teachers. OPUS International Journal of Society Researches, 7(12), 33-53.

Doğan, S. (2015). Üstün yetenekli öğrencilerin psikolojik ihtiyaçlarının bazı değişkenlere göre incelenmesi (Yayımlanmamış Yüksek Lisans Tezi). Necmettin Erbakan Üniversitesi Eğitim Bilimleri Enstitüsü, Konya.

Döş, İ. (2016). Lise öğrencilerinin görüşlerine göre okul müdürlerinin liderlik becerisi ölçeğinin geliştirilmesi. Gazi Üniversitesi Gazi Ĕ̆itim Fakültesi Dergisi, 36(1), 113-139.

Emir, S. ve Acar, S. (2007). Zekâ-Liderlik İlişkisi: Üstün zekâlı olan ve olmayan öğrencilerin liderlik becerilerinin karşılaştırılması. Hasan Ali Yücel Ĕ̆ilim Fakültesi Dergisi, 2, 189-201. 
Ersoy, E. ve Deniz, M.E. (2016). Üstün yetenekli çocukların öfkeyle başa çıkma ve karar verme becerilerinin bazı değişkenler açısından incelenmesi. İlköğretim Online, 15(3), 1017-1030.

Eskicumalı A. ve Eroğlu, E. (2001). Ailenin sosyo-ekonomik ve eğitim düzeyleri ile çocukların problem çözme yetenekleri arasındaki ilişki. Sakarya Üniversitesi Ĕ̈itim Fakültesi Dergisi, 1, 165-189.

Karasar, N. (2002). Bilimsel Araştırma Yöntemi, Nobel Yayıncılık, Ankara.

Kılınç, A. Ç. ve Özdemir, S. (2016). Liderlik kapasitesi, Pegem Yayın, Ankara.

Koç, İ. (2015). Bilim ve sanat merkezi'ne devam eden özel yetenekli öğrencilerin iletişim becerileriyle ilgili görüşleri. Üstün Yetenekliler Ĕ̆gitimi Araştırmaları Dergisi, 1(3), 39-53.

Korkmaz, M. (2006). Okul yöneticilerinin kişilik özellikleri ile liderlik stilleri arasındaki ilişki. Kuram ve Uygulamada Ĕ̆itim Yönetimi, 46, 199226.

Kulaksızoğlu, A. (1990). Gençlik çağı ve ülkemizde gençlik sorunları. Marmara Üniversitesi Eğitim Bilimleri Dergisi, 2, 133-144.

Levent, F. (2012). Bilsem öğretmenlerine göre üstün yetenekli öğrencilerin sosyo-duygusal özellikleri. Geleceğin Mimarları Üstün Yetenekliler Sempozyumu. Namık Kemal Üniversitesi Sağlık Hizmetleri Meslek Yüksekokulu, 27 Nisan, Tekirdağ.

MEB (Milli Eğitim Bakanlığı). (2016). Özel Yetenekli Öğrencilerin Seçim Süreci Başladı, Erişim tarihi: 20.11.2016, http://www.meb.gov.tr/ozelyetenekli-ogrenci-secim-sureci-basladi/haber/12270/tr

MEB (Milli Eğitim Bakanlığı). (2016a). Bilim ve Sanat Merkezleri Yönergesi, Erişim tarihi: 06.11.2016, http://orgm.meb.gov.tr/

Ogurlu, Ü. (2012). Liderlik becerileri geliştirme programının üstün zekâlı olan ve olmayan öğrencilerin liderlik becerilerine etkisi (Yayımlanmamış Doktora Tezi). İstanbul Üniversitesi, Sosyal Bilimler Enstitüsü, İstanbul.

Ogurlu, Ü ve Yavuz, Y. (2010). Üstün zekâlı/yetenekli çocuklar ve iletişim. Pamukkale Üniversitesi Eğitim Fakültesi Dergisi, 28, 213-223.

Saban, A. (2008). Okula ilişkin metaforlar. Kuram ve Uygulamada Ĕ̆itim Yönetimi, 55, 459-495.

Şimşek, H. ve Yıldırım, A. (2011). Sosyal bilimlerde nitel araştırma yöntemleri. Seçkin Yayıncılık, Ankara. 
Şenel, T. ve Aslan, O. (2014). Okul öncesi öğretmen adaylarının bilim ve bilim insanı kavramlarına ilişkin metaforik algıları. Mersin Üniversitesi Eğitim Fakültesi Dergisi, 10 (2).

TBMM (Türkiye Büyük Millet Meclisi). (2012). Üstün yetenekli çocukların keşfi, eğitimleriyle ilgili sorunların tespiti ve ülkemizin gelişimine katkı sağlayacak etkin istihdamlarının sağlanması amacıyla kurulan meclis araştırması komisyonu raporu, Erişim tarihi:10.11.2016, http://acikerisim.tbmm.gov.tr:8080/xmlui/handle/11543/129

Toprak E. ve Bozgeyikli, H. (2011). Öğretmen adaylarının sosyal sermaye düzeylerinin karşılaştırmalı incelenmesi (Erciyes Üniversitesi Örneği). Erciyes Üniversitesi Sosyal Bilimler Enstitüsü Dergisi, 125-147.

Toprak E. ve Selçuklu, A. E. (2012). Öğretmen adaylarının sosyoekonomik düzeyleri ile LYS puanları arasındaki ilişkinin incelenmesi. OPUS Turkish Journal of Social Policy and Labour Life Studies, 2(3), 44-61.

Tuncer, M. (2016). Yetenek mi? Zekâ mı? Üstün niteliklileri seçmeye eleştirel bir bakış. Ĕ̆itime Bakış, 12(37), 3-10.

Tüysüz B. (2007). Öğrenci Liderliği Programı́nın 6. sınıf öğrencilerinin liderlik rolleri ve davranışlarına etkisinin incelenmesi (Yayınlanmamış Doktora Tezi). Marmara Üniversitesi Eğitim Bilimleri Enstitüsü, İstanbul.

\section{Kaynakça Bilgisi / Citation Information}

Demirçelik, E., Karacabey, A. S. ve Cenan, A. D. (2017). Özel yetenekli öğrencilerin liderlik becerilerinin bazı değişkenler açısından incelenmesi. OPUS - Uluslararası Toplum Araştırmaları Dergisi, 7(13), 399425 . 